\title{
T cell depletion in untreated adult coeliac disease
}

\author{
D. P. O'DONOGHUE, M. LANCASTER-SMITH ${ }^{1}$, PETRONA LAVINIERE, AND \\ PAR VEEN J. KUMAR ${ }^{2}$
}

From the Department of Gastroenterology, St Bartholomew's Hospital, London

SUMMARY The proportional and absolute numbers of circulating thymus dependant lymphocytes ( $T$ cells) were reduced in untreated patients with coeliac disease but were normal after treatment with a gluten free diet. There was an inverse correlation between circulating $T$ cell numbers and jejunal intraepithelial lymphocytes. This evidence suggests a possible role for $T$ cells in the pathogenesis of coeliac disease and is a further example of disturbed cell mediated immunity in this condition.

Thymus dependant lymphocytes ( $\mathrm{T}$ cells) may be involved in the pathogenesis of the jejunal lesion in coeliac disease (Ferguson, 1974). In addition, impaired function of circulating lymphocytes, probably $\mathrm{T}$ cells, occurs in this disorder (Blecher et al., 1969; McClaurin et al., 1971). The numbers of circulating $\mathrm{T}$ lymphocytes in coeliac disease might have an important bearing upon these phenomena. The aim of this study, therefore, was to quantitate peripheral blood cells that spontaneously form rosettes with sheep red cells which are considered to represent the $\mathbf{T}$ cell subpopulation (Jondal et al., 1972; Wybran et al., 1973). The findings have been correlated with dietary treatment and lymphocyte populations of the jejunal mucosa in an attempt to elucidate the possible role of $\mathrm{T}$ cells in coeliac disease.

\section{Methods}

LYMPHOCYTE SEPARATION

Defibrinated blood was diluted by adding 3 parts phosphate buffered saline (PBS) to 1 part blood, layered on to a sodium metrizoate-Ficoll solution (Nyegaard \& Co. As., Oslo) and centrifuged at 650 $\times g$ for 30 minutes at $20^{\circ} \mathrm{C}$. The separated lymphocytes were now washed twice in Eagle's medium at $4^{\circ} \mathrm{C}$ and finally resuspended in Eagle's medium to an approximate concentration of $2 \times 10^{7}$ per $\mathrm{ml}$.

ROSETTE TEST

Sheep red blood cells (SRBC) were washed twice in PBS at $4^{\circ} \mathrm{C}$ and finally resuspended in Eagle's

\footnotetext{
${ }^{1}$ Present address : Queen Mary's Hospital, Sidcup, Kent.

Address for reprint requests: Dr. P. J. Kumar, Department of Gastroenterology, St Bartholomew's Hospital, London EC1A 7BE. Received for publication 11 February 1976
}

medium to a concentration of approximately $40 \times$ $10^{6} \mathrm{cell} / \mathrm{s} / \mathrm{ml}$. The remainder of the test was performed according to the method of Wybran (Wybran et al., 1973). The numbers of rosette forming lymphocytes were expressed both as a percentage of the total lymphocyte population and as absolute numbers per $\mathrm{ml}$ of blood, calculated from the formula, white cells per $\mathrm{ml}$ of blood $\times$ percentage lymphocytes $\times$ percentage rosette forming cells. A rosette was defined as a lymphocyte surrounded by at least 3 SRBC. The yield of lymphocytes was consistently greater than $80 \%$. Groups of patients and controls were always studied concurrently.

\section{JEJUNAL BIOPSIES}

These were obtained from 19 patients by Crosby capsule from the duodenojejunal flexure coincident with blood lymphocyte studies. Sections $5 \mu$ thick were stained with haemotoxylin and eosin. Jejunal lamina propria lymphocytes were counted and expressed as lymphocytes per $\mathrm{mm}^{2}$ of mucosa (Lancaster-Smith et al., 1975). Intraepithelial lymphocytes were counted and expressed as lymphocytes per 100 epithelial cells (Ferguson and Murray, 1971). At least 500 epithelial cells were counted.

\section{Patients}

The groups studied were 24 patients with treated adult coeliac disease, 29 untreated patients, and 39 controls of comparable age and sex distribution and nutritional status. Nine patients were studied both before and after treatment with a gluten free diet. Ten patients with malabsorption due to conditions other than coeliac disease were also studied (Table 1). The degree of malabsorption in this group was, in general, more severe than in the patients with untreated coeliac disease. 


\begin{tabular}{lc}
\hline Cause of malabsorption & $\begin{array}{l}\text { Patients } \\
\text { (no) }\end{array}$ \\
\hline Small bowel bypass for obesity & 3 \\
Chronic pancreatitis & 2 \\
Jejunal diverticula & 1 \\
Tropical sprue & 1 \\
Partial gastrectomy & 1 \\
Biliary obstruction & 1 \\
a-chain disease & 1 \\
& 10 \\
\hline
\end{tabular}

Table 1 Cases of malabsorption not due to coeliac disease

\begin{tabular}{|c|c|c|c|c|}
\hline & Nos & $\begin{array}{l}T \text { cells } \\
(\%)\end{array}$ & $T$ cells $/ m l^{*}$ & $\begin{array}{l}\text { Total } \\
\text { lymphocytes } \\
\text { ml* }\end{array}$ \\
\hline \multicolumn{5}{|l|}{ Coeliacs } \\
\hline Untreated & 29 & $42 \cdot 4 \pm 1.7$ & $577 \pm 51$ & $1340 \pm 95.5$ \\
\hline Treated & 24 & $62 \pm 1.6$ & $1050 \pm 95.5$ & $1674 \pm 141$ \\
\hline Controls & 39 & $59 \pm 1.5$ & $942 \pm 58$ & $1604 \pm 86$ \\
\hline
\end{tabular}

Table 2 Peripheral blood $T$ cells in adult coeliac disease

Means $\pm \mathrm{SE} ; *$ Multiply by $10^{3}$.

\section{Results}

The proportional and absolute numbers of $T$ lymphocytes in the peripheral blood of patients with untreated ACD were decreased when compared with treated patients $(\mathrm{P}<0.002, \mathrm{P}<0.002)$ controls $(\mathrm{P}<0.002, \mathrm{P}<0.002)$ and patients with malabsorption not due to coeliac disease $(P<0.002$, $P<0.05$ ). Treated patients had the same proportional and absolute numbers of $T$ cells as controls (Figs 1 and 2). Unlike T lymphocytes, total peripheral

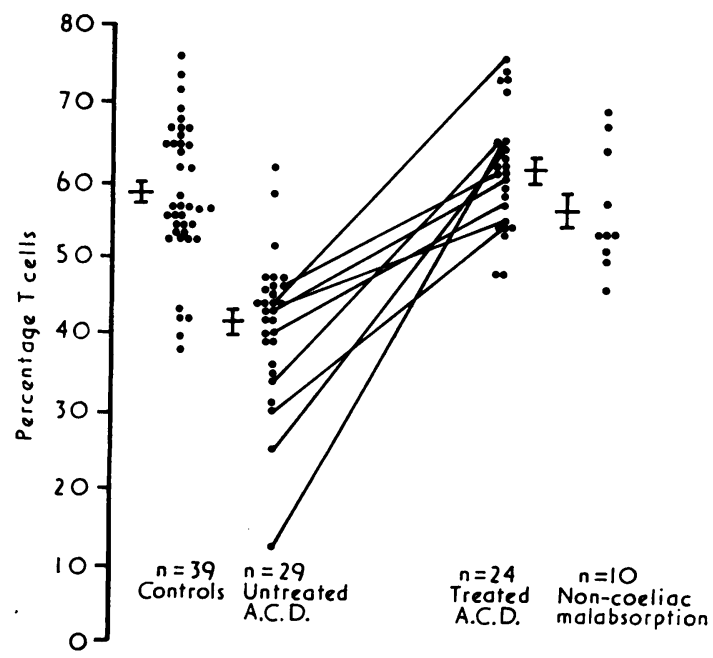

Fig. 1 Rosette-forming $T$ lymphocytes in peripheral blood as a percentage of total lymphocytes. blood lymphocytes did not differ significantly in the four groups (Tabl z 2). All nine patients studied both before and after treatment with a gluten free diet showed a proportional rise in T cells $(P<0.001)$ and seven of nine an increase in absolute cell numbers (P < 0.025) (Figs 1 and 2).

Jejunal intraepithelial lymphocyte counts showed an inverse correlation with the proportional $(P<$ $0.001)$ (Fig. 3) and absolute $(P<0.01)$ peripheral blood $T$ cell counts. In contrast, there was no correlation between peripheral blood $\mathrm{T}$ cells and jejunal lamina propria lymphocytes or between total

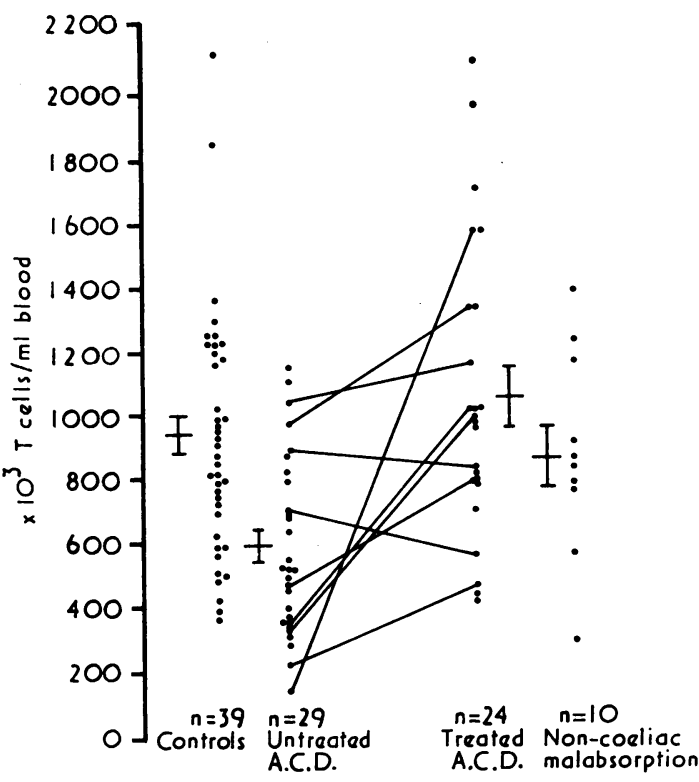

Fig. 2 Rosette-forming T lymphocytes in peripheral blood as absolute numbers.

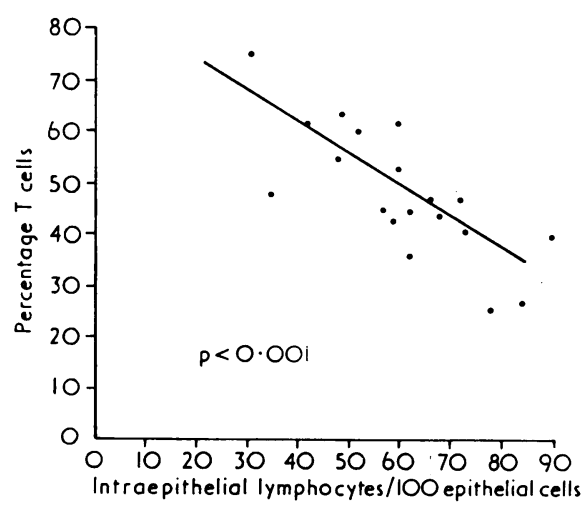

Fig. 3 Correlation between peripheral blood $T$ lymphocytes and jejunal intraepithelial lymphocytes. 
peripheral blood lymphocytes and jejunal intraepithelial or lamina propria lymphocytes.

\section{Discussion}

The depletion of circulating $\mathbf{T}$ cells in untreated coeliac disease might be due to impaired production, increased sequestration in lymphoreticular tissue (the most likely areas being small bowel mucosa and mesenteric lymph nodes), or excessive loss into the gut lumen. Which one or combination of these is responsible is not clear but the return to normal levels after treatment with a gluten free diet implies that it is a secondary phenomenon. In untreated coeliac disease there is an excess of lymphocytes in the epithelial cell layer of the jejunum (Ferguson and Murray, 1971; Ferguson et al., 1974) and increased loss of lymphocytes into the gut lumen (Weetman et al., 1974), both of which are also reversed by treatment. If the depletion of circulating $\mathrm{T}$ cells be due to these mechanisms, it would imply a selective sequestration or loss of $\mathrm{T}$ cells compared with non$T$ cells, but whether this is so remains unknown. However, in immunohistochemical studies of the jejunal mucosa in coeliac disease, cells of lymphocyte proportions staining with anti-immunoglobulin sera, which are presumed to be B lymphocytes, have been found only in the lamina propria and not in the epithelial cell layer (Rubin et al., 1965; LancasterSmith et al., 1974). This indirectly suggests that the great majority of intraepithelial lymphocytes are nonimmunoglobulin bearing $T$ cells. The inverse correlation between the degree of circulating $T$ cell depletion and the increase of intraepithelial lymphocytes would support this. Alternatively, both phenomena might be two unrelated features of untreated coeliac disease (Marsh, 1975).

Circulating lymphocytes from patients with untreated coeliac disease show reduced blast transformation in response to the gliadin fraction of gluten when compared with treated patients (Asquith, 1974). This, Asquith believes, is due to large numbers of gliadin sensitized lymphocytes leaving the blood and sequestering in the small bowel mucosa of untreated patients. Our findings would support this hypothesis and suggest that the majority of lymphocytes attracted to the gut are $T$ cells. The lymphoreticular dysfunction (McCarthy et al., 1966), impaired blast transformation produced by non-specific mitogens (Blecher et al., 1969; Asquith, 1974), reduced cytotoxic capacity of lymphocytes against tumour cells in vitro (McClaurin et al., 1971), and the increased incidence of gut lymphomas found in coeliac disease (Austad et al., 1967; Harris et al., 1967) are considered to be evidence of cell mediated immunodysfunction in this condition. The depletion of $T$ cells, which are of prime importance in cell mediated reactions, could therefore have some bearing on these deficiencies and it might be that the return to normal numbers of $T$ cells after a gluten free diet is the reason for the reduced incidence of gut neoplasms in treated coeliacs compared with untreated patients (Harris et al., 1967; Holmes et al., 1974).

In conclusion, it seems possible that $T$ lymphocytes may be involved in the pathogenesis of coeliac disease and that their depletion in untreated patients may partly explain the associated cell mediated immunodysfunction. However, a role for $\mathrm{T}$ cells does not necessarily imply that cell mediated mechanisms per $s e$ are involved in the small bowel lesion of coeliac disease because $\mathrm{T}$ cells are also important in humoral immune mechanisms, some of which have been implicated in the pathogenesis of this disorder (Lancet, 1974).

The finding of normal numbers of circulating $T$ lymphocytes in patients with malabsorption from conditions other than coeliac disease, whose general state was comparable with the patients with untreated coeliac disease, makes it extremely unlikely that the $\mathrm{T}$ cell depletion in this latter group is a manifestation of malabsorption per se.

We would like to thank $\operatorname{Dr}$ A. M. Dawson for allowing us to study patients under his care and the Medical College of St. Bartholomew's Hospital and the Action Research for the Crippled Child for their financial support.

\section{References}

Asquith, P. (1974). Cell mediated immunity in coeliac disease. In Coeliac Disease, pp. 242-262. Edited by W. Th. Hekkens and A. S. Pena. Second International Coeliac Symposium, Leiden. Stenfert Kroese: Leiden.

Austad, W. I., Cornes, J. S. Gough, K. R., McCarthy, C. F., and Read, A. E. (1967). Streatorrhoea and malignant lymphoma. American Journal of Digestive Diseases, 12, 475-490.

Blecher, T. E., Brzechaw-Ajdukiewicz, A., McCarthy, C. F., and Read, A. E. (1969). Serum immunoglobulins and lymphocyte transformation studies in coeliac disease. Gut, 10, 57-62.

Ferguson, A. (1974). Lymphocytes in coeliac disease. In Coeliac Disease, pp. 265-276. Edited by W. Th. Hekkens and A. S. Pena. Second International Coeliac Symposium, Leiden. Stenfert Kroese: Leiden.

Ferguson, R., Asquith, P., and Cooke, W. T. (1974). The jejunal cellular infiltrate in coeliac disease complicated by lymphoma., Gut, 15, 458-461.

Ferguson, A. and Murray, D. (1971). Quantitation of intraepithelial lymphocytes in human jejunum. Gut, 12, 988994.

Harris, O. D., Cooke, W. T., Thompson, H., and Waterhouse, J. A. H. (1967). Malignancy in adult coeliac disease, and idiopathic steatorrhoea. American Journal of Medicine, 42, 899-912. 
Holmes, G. K. T., Stokes, P. L., McWalter, R., Waterhouse, J. A. H., and Cooke, W. T. (1974). Coeliac disease, malignancy, and a gluten-free diet. Gut, 15, 339.

Jondal, M., Holm, G., and Wigzell, H. (1972). Surface markers on human $T$ and $B$ lymphocytes. 1. A large population of lymphocytes forming non-immune rosettes with sheep red cells. Journal of Experimental Medicine, 136, 207-215.

Lancaster-Smith, M., Kumar, P., Marks, R., Clark, M. L., and Dawson, A. M. (1974). Jejunal mucosal immunoglobulin-containing cells and jejunal fluid immunoglobulins in adult coeliac disease and dermatitis herpetiformis. Gut, 15, 371-376.

Lancaster-Smith, M., Kumar, P. J., and Dawson, A. M. (1975). The cellular infiltrate of the jejunum in adult coeliac disease and dermatitis herpetiformis following the reintroduction of dietary gluten. Gut, 16, 683-688.

Lancet (1974). Editorial. The coeliac philosophy. Lancet, 2, 501-502.
McCarthy, C. F., Fraser, I. D., Evans, K. T., and Read, A. E. (1966). Lymphoreticular dysfunction in idiopathic steatorrhoea. Gut, 7, 140-148.

McClaurin, B. P., Cooke, W. T., and Ling, N. R. (1971). Impaired lymphocyte reactivity against tumour cells in patients with coeliac disease. Gut, 12, 794-800.

Marsh, M. N. (1975). Studies of intestinal lymphoid tissue. 1. Electron microscopic evidence of 'blast transformation' in epithelial lymphocytes of mouse small intestinal mucosa. Gut, 16, 665-674.

Rubin, W., Fauci, A. S., Sleisenger, M. H., and Jeffries, G. H. (1965). Immunofluorescent studies in adult celiac disease. Journal of Clinical Investigation, 44, 475-485.

Weetman, A. P., Haggith, J., and Douglas, A. P. (1974). Enteric loss of lymphocytes in coeliac disease and in Crohn's disease. Gut, $15,823$.

Wybran, J., and Fudenberg, H. (1973). Thymus derived rosette forming cells in various human disease states: cancer, lymphoma, bacterial and viral infections and other diseases. Journal of Clinical Investigation, 52, 1026-1032. 